\title{
DINAMISME WAKAF UNIT AMANAH MENURUT PERSPEKTIF SYARAK
}

\section{Dynamism of Waqf of Unit Trusts from Shariah Perspective}

\author{
Syahnaz Sulaiman ${ }^{1}$ \\ Aznan Hasan ${ }^{2}$
}

\begin{abstract}
The majority of waqf assets available across the Muslim world today consist of immovable property such as land and buildings; all of which conform to Shariah principles. In line with the global changes and current needs, dedicated assets for the purpose of waqf have evolved from movable to immovable assets to include cash, stocks and bonds. However, the discussion pertaining to Shariah ruling and the procedures of managing this category of waqf assets is still limited. The concept of waqf of unit trusts is still new and more research needs to be carried out for better comprehension and implementation. The question arises with regards to the position of unit trust as the subject of waqf given that it has no distinct and permanent features which allow for it to be transferable from one hand to another. Accordingly, this study will discuss the Islamic legal ruling and the procedures of managing waqf of unit trusts within the framework of Islamic law.
\end{abstract}

\footnotetext{
1 Senior Assistant Director, Strategic Planning and Research Division, Department of Islamic Development Malaysia, syahnaz@islam.gov.my

2 Associate Professor, IIUM Institute of Islamic Banking and Finance Institution (IIiBF), International Islamic University Malaysia, aznanh@gmail.com
} 
This study is qualitative in nature, involving document analyses of journal articles, books and policy documents as well as in-depth interviews with experts. The findings conclude that unit trusts have been regarded as a permissible waqf object. This study also outlines the procedure for a prudent management of waqf of unit trusts to ensure the application is consistent with the principles of Shariah.

Keywords: waqf, unit trusts, development

\section{PENGENALAN}

Sejak berabad lamanya institusi wakaf telah memainkan peranan yang signifikan terhadap pembangunan peradaban Islam selain menyumbang kepada kemakmuran serta kesejahteraan sosioekonomi ummah. Objektif utama pembangunan harta wakaf adalah bagi menjamin kelestarian agihan manfaat wakaf kepada para benefisiari dalam merealisasikan hasrat pewakaf yang mengharapkan ganjaran pahala yang berterusan daripada Allah SWT atas prinsip qurbah yakni mendekatkan diri kepada Allah SWT. Sejarah melakarkan bukti bahawa sebahagian besar aset wakaf yang diabadikan untuk kemaslahatan ummah terdiri daripada harta-harta tak alih. Aset-aset wakaf seterusnya melalui proses revolusi sejajar dengan perkembangan disiplin ilmu muamalat Islam yang bersifat murūnah bagi memenuhi aspirasi tuntutan semasa. Harta wakaf tidak lagi terhad kepada aset dalam bentuk tak alih, bahkan turut merangkumi aset-aset dalam kategori harta alih seperti wang tunai dan saham syarikat. Kajian ini merupakan kajian berbentuk kualitatif melibatkan analisis dokumen seperti artikel jurnal, buku dan dokumen polisi serta temu bual dengan pakar bagi mengukuhkan hasil dapatan kajian. Kajian ini secara dasarnya menjelaskan tentang konsep serta sumbangan wakaf kepada kemajuan sosioekomi serta hukum mewakafkan unit amanah termasuk tatacara pengurusan aset berkenaan menurut kerangka hukum Syarak. Sehubungan itu, artikel ini dikemukakan bertujuan untuk meneroka prospek alat kewangan kontemporari iaitu unit amanah dalam menilai potensinya sebagai subjek wakaf. 


\section{KONSEP WAKAF DAN SUMBANGAN DALAM EKONOMI}

Perkataan wakaf berasal daripada kata dasar dalam bahasa Arab waqafa. Daripada sudut bahasa, al-waqf bermaksud al-qat' iaitu berhenti. ${ }^{3}$ Dalam konteks muamalat Islam, al-waqf adalah sinonim dengan al-habs yang bermaksud penahanan, al-man " bererti larangan ${ }^{4}$ serta al-tasbil iaitu menyalurkan pada jalan Allah. Daripada sudut istilah, wakaf merupakan suatu pemberian atau dedikasi yang melibatkan pengorbanan harta oleh seorang individu Muslim ke arah kebaikan ${ }^{5}$ atas dasar qurbah yakni mendekatkan diri kepada Allah SWT bagi mendapat keredaan dan ganjaran pahala (thawab) yang berkekalan daripada-Nya. ${ }^{6}$ Hakikatnya konsep wakaf adalah menjangkaui pengertian ibadah yang mengatur hubungan ketaatan manusia kepada Allah SWT (habl min Allah) kerana turut merangkumi aspek muamalah bagi memelihara hubungan sesama insan (habl min al-nas) yang berpaksikan nilai-nilai persaudaraan (ukhuwwah), kasih sayang (mahabbah), kerjasama dan saling bantu-membantu (ta 'awun) ${ }^{7}$ ke arah kebaikan (jihhah al-bir). ${ }^{8}$ Institusi wakaf telah disyariatkan dalam Islam dan berperanan sebagai alat jaringan keselamatan sosial dan ekonomi bagi menjamin agihan kekayaan yang seimbang dalam masyarakat setanding dengan peranan yang dimainkan oleh zakat. Lantaran itu, hak dan kebajikan golongan miskin dan memerlukan turut dibela dan dipelihara menerusi fungsi wakaf. Pendekatan ini adalah selaras dengan ajaran Islam yang menganjurkan konsep persaudaraan serta keadilan ekonomi

3 Majmā' al-Lughah al-‘Arabiyyah, al-Mu 'jam al-Wașiț, vol. 2 (Qāhirah: Maktabah al-Shuruq al-Dawliyyah, 2004), 1051.

4 Shams al-Dīn al-Sarakhsī, al-Mabșūt, vol. 12 (Beirūt: Dār al-Ma'rifah, t.t.), 27.

5 Menurut Syeikh Muḥammad Abū Zahrah, ciri-ciri kebaikan yang menjadi intipati wakaf tidak hanya terhad kepada aspek peribadatan seperti pembinaan masjid tetapi turut merangkumi wakaf kepada fakir miskin, golongan yang memerlukan, hamba sahaya dan wakaf menerusi pemberian pinjaman qard al-hasan daripada hasil pulangan wakaf. Lihat Abū Zahrah, Muhạạdarāt fì al-Waqf (t.t.p.: Matba'ah 'Alī Mukhaymar, 1959), 8.

6 Mușțafā Aḥmad al-Zarqa', al-Ahkām al-Awqāf (Amman: Dār 'Ammar, 1998), 19; Wahbah al-Zuhaylī, al-Wașāyā wa al-Waqf fì al-Fiqh al-Islamī (Damshiq: Dār al-Fikr, 1987), 134-135. Miriam Hoexter, Endowments, Rulers and Community: Waqf al-Haramayn in Ottoman Algiers (Leiden: Brill, 1998), 8.

7 Syahnaz Sulaiman, 'Hukum Pembangunan Tanah Wakaf Khas menurut Perspektif Syarak,' Jurnal Muamalat, 1 (2008): 51.

8 Al-Zarqa', al-Ahkām al-Awqāf, 14; Sabri, al-Waqf al-Islāmī bayna al-Nazariyyah wa al-Tațiiq, 17; Monzer Kahf, 'The Role of Waqf in Improving the Ummah Welfare,' (Makalah, Waqf as a Private Legal Body, University of North Sumatra, 6-7 Januari 2003), 3. 
Sungguhpun pensyariatan wakaf tidak dinyatakan secara spesifik dalam al-Quran, ${ }^{9}$ sumbangan wakaf amat signifikan terhadap ketamadunan umat manusia dalam dunia Islam mengatasi konsep sedekah yang biasa. Ini disebabkan konsep wakaf menggabungkan elemen-elemen holistik melibatkan pertimbangan darisudut ekonomi dan amal kebajikan yang dijanjikan ganjaran pahala yang berkekalan. Lantaran itu, wakaf diberikan kedudukan yang tinggi sebagai șadaqah jāriyah berbanding dengan pemberian biasa dengan menjanjikan ganjaran pahala yang berterusan dan berkekalan di dunia dan akhirat kepada mereka yang melaksanakannya. ${ }^{10}$ Berdasarkan hujah inilah, majoriti ulama berpegang kepada pemahaman mereka terhadap nas hadis yang menolak wakaf yang dibuat secara bertempoh atas dasar bahawa pengabdian diri kepada Allah SWT melalui konsep wakaf seharusnya tidak bersifat sementara sebaliknya hendaklah berterusan dan kekal ${ }^{11}$ bagi menjamin ganjaran pahala yang berterusan kepada pewakaf.

Terdapat satu hadis yang diriwayatkan oleh Ibn Umar mengenai tindakan ayahandanya Sayyidina Umar al-Khattab yang telah mewakafkan sebidang tanah pertanian kesayangannya di Khaybar berupa sebuah ladang kurma. Hadis tersebutmerupakan suatu manifestasi yang jelas bahawa harta wakaf hendaklah terdiri daripada harta yang bersifat produktif dan menjana hasil untuk diagihkan kepada golongan yang memerlukan. ${ }^{12}$ Hadis ini secara tidak

9 Timur Kuran, 'The Provision of Public Goods Under Islamic Law: Origins, Impact, and Limitations of the Waqf System,' Law and Society Review, 35 (2001): 844.

10 Kenyataan ini adalah berlandaskan kepada hadis berhubung tiga amalan yang dijanjikan Allah SWT dengan ganjaran yang berpanjangan meskipun selepas kematian pemberi iaitu doa anak yang soleh, ilmu yang bermanfaat dan sedekah jariah yakni sedekah yang berpanjangan merujuk kepada wakaf. Hadis riwayat Muslim, no. hadis 1631, Kitab Wașiyyah, Bāb Mā Yalhagu al-Insān min al-Thawab ba'da Wafātihi; Tirmidhī, no. hadis 1376, Kitāb al-Ahkām Rasūlullah SAW, Bāb al-Waqf. Lihat Abū al-Ḥusayn Muslim bin al-Hajjāj al-Qushayrī, 'Ṣahīḥ Muslim', Mawsū 'ah al-Hadīth al-Sharīf: al-Kutub al-Sittah, ed. Sālih Ibn 'Abd al-'Aziz Ibn Muhammad Ibn Ibrāhim al-Shaykh (Riyāẹ: Dār al-Salām, 2008), 963; Muhammad Ibn 'Īsā, 'Jāmi' al-Tirmidhī', Mawsū 'ah al-Hadīth al-Sharīf: al-Kutub al-Sittah, ed. Sālih Ibn 'Abd al-'Aziz Ibn Muḥammad Ibn Ibrāhim al-Shaykh (Riyāḍ: Dār al-Salām, 2008), 1791.

11 Wahbah al-Zuhaylī, al-Wașāyā wa al-Waqf fì al-Fiqh al-Islāmī (Damshiq: Dār alFikr, 1987), 205.

12 Hadis ini telah diriwayatkan oleh semua perawi dalam kitab Sunan al-Sittah. Hadis riwayat al-Bukhāri, Kitāb al-Wasāyā, Bāb al-Waqf li al-Ghaniyyi wa alFāqir wa al-Dā'if, no. hadis 2764; Muslim, Kitab al-Wasiyyah, Bāb al-Waqf, no. hadis 4224; Ab̄̄ Dāwud, Kitāb al-Farā'id, Bāb Mā Jā’a fi al-Rajul Yuqafu al-Waqf, 
langsung menjadi gagasan dan landasan yang penting dalam membentuk teori pembangunan harta wakaf secara lestari yang menekankan aspek kemapanan sumbangan wakaf terhadap kemajuan sosioekonomi ummah secara berterusan. Sehubungan itu, amalan wakaf yang bercirikan kekal terus berkembang dan menjadi tradisi serta teras kepada pembinaan kekayaan serta ketamadunan ${ }^{13}$ Islam semenjak zaman Nabi Muhammad SAW sehingga ke hari ini. Pendek kata, baik di mana sahaja umat Islam berada di pelosok bumi ini, merentasi lautan Atlantik dan Pasifik, amalan kebajikan dan kedermawanan berasaskan wakaf turut sama berkembang dan menjadi asas dalam menghidupkan fungsi sebuah peradaban. Wakaf turut melahirkan rangkaian bangunan yang mempunyai sentuhan seni bina dan landskap bercirikan Islam yang unik seperti Taj Mahal di India, jambatan Mortar di Bosnia, Masjid al-Aqsa di Palestine serta ikon-ikon lain seperti Universiti al-Azhar di Mesir, Hospital Kanak-Kanak Sisli di Istanbul dan Terusan Air Zubaidah di Mekah. ${ }^{14}$

Catatan sejarah seterusnya melakarkan bukti bahawa institusi wakaf telah berperanan secara dominan sebagai salah satu komponen dalam sektor

no. hadis 2878; Tirmidhī, Bāb Mā Ja'a fi al-Waqf, no. hadis 1375, al-Nasā'i, Kitāb al-Ihbas, no. hadis 3637; Ibn Mājah, Kitāb Sadaqāt, Abwab al-Sadaqat, no. hadis 2397. Lihat Abū 'Abd Allāh Muḥammad bin Ismā'il al-Bukhārī, 'Șaḥị̄ alBukhārī,' Mawsū 'ah al-Hadīth al-Sharīf: al-Kutub al-Sittah, ed. Sālih Ibn 'Abd al-‘Aziz Ibn Muhammad Ibn Ibrāhim al-Shaykh (Riyāḍ: Dār al-Salām, 2008), 223; Abū al-Ḥusayn Muslim bin al-Hajjaj al-Qushayrī, 'Șaḥị̣ Muslim', Mawsū 'ah alHadīth al-Sharīf: al-Kutub al-Sittah, ed. Sāliḥ Ibn 'Abd al-'Aziz Ibn Muhammad Ibn Ibrāhim al-Shaykh (Riyāḍ: Dār al-Salām, 2008), 963; Abī Dāwud Sulayman Ibn al-Ash'ath, 'Sunan Abī Dāwud', Mawsū'ah al-Hadīth al-Sharīf: al-Kutub al-Sittah, ed. Sālih Ibn 'Abd al-'Aziz Ibn Muḥammad Ibn Ibrāhim al-Shaykh (Riyāụ: Dār al-Salām, 2008), 1438; Muḥammad Ibn 'Isā Ibn Thawrah, 'Jami' alTirmidhī', Mawsū 'ah al-Hadīth al-Sharīf: al-Kutub al-Sittah, ed. Sālih Ibn 'Abd al-'Aziz Ibn Muḥammad Ibn Ibrāhim al-Shaykh (Riyāḍ: Dār al-Salām, 2008), 1791; Abī 'Abd al-Rahmān Ahmad Ibn Shu'ayb al-Nasā'i, Mawsū 'ah al-Hadīth al-Sharīf: al-Kutub al-Sittah, ed. Sālih Ibn 'Abd al-'Aziz Ibn Muhammad Ibn Ibrāhim al-Shaykh (Riyāḍ: Dār al-Salām, 2008), 2326; Muhammad Ibn Yazid alQazwini, 'Sunan Ibn Majah,' Mawsū'ah al-Hadīth al-Sharīf: al-Kutub al-Sittah, ed. Sālih Ibn 'Abd al-'Aziz Ibn Muhammad Ibn Ibrāhim al-Shaykh (Riyāḍ: Dār al-Salām, 2008), 2620.

13 Yildrim, Riza, 'Dervishes Waqfs, and Conquest: Notes on Early Ottoman Expansion in Thrace,' dalam Held in Trust: Waqf in the Islamic World, ed. Ghazaleh, Pascale (New York: The American University in Cairo Press, 2011), 23.

14 Siraj Sait \& Hilary Lim, Land Law and Islam: Property Human Rights in the Muslim World (London: Zed Books Ltd, 2006), 147. 
ketiga yang membiayai pembangunan sosioekonomi ummah. Ini termasuk menyediakan infrastruktur asas bagi memenuhi tuntutan dan keperluan sosial umat Islam berkaitan keagamaan, pendidikan, kesihatan, pertanian, penyelidikan, pemeliharaan alam sekitar dan haiwan, pembiayaan mikro, penyediaan infrastruktur awam ${ }^{15}$ termasuk pembelaan golongan yang kurang bernasib baik. Timur Kuran menyifatkan bahawa wakaf sebagai institusi amanah telah menyumbang terhadap kemajuan bandar-bandar di wilayah Islam lebih besar daripada kemajuan yang dikecapi oleh Barat pada era pertengahan (middle age) dengan membiayai pembinaan dan penyelenggaraan pelbagai perkhidmatan perbandaran tanpa melibatkan $\operatorname{kos}^{16}$ dan campur tangan oleh kerajaan. ${ }^{17}$ Sumbangan dan peranan wakaf yang begitu signifikan ini secara tidak langsung telah mengurangkan bebanan perbelanjaan yang ditanggung oleh kerajaan dalam memelihara aspek kebajikan sosial sehingga Hodgson mengungkapkan fungsi wakaf sebagai "a vehicle for financing Islam as a society" iaitu sebagai jentera yang membiayai Islam sebagai sebuah masyarakat. ${ }^{18}$

\section{LATAR BELAKANG KAJIAN}

Institusi wakaf walau bagaimanapun mengalami era kemerosotan kerana dihimpit oleh pelbagai masalah. ${ }^{19}$ Masalah kekurangan dana ${ }^{20}$ merupakan

15 Monzer Kahf, 'Waqf and Its Sociopolitical Aspects,' dalam Essential Readings in Contemporary Waqf Issues, ed. Kahf, Monzer \& Siti Mashitoh Mahamood (Kuala Lumpur: CERT Publications, 2011), 46.

16 Magda Ismail Abdel Mohsin, 'Revitalization of Waqf Administration \& Family Waqf Law,' US-China Law Review, 7/6 (June 2010): 1.

17 Timur Kuran, 'The Absence of the Corporation in Islamic Law: Origins and Persistence,' American Journal of Comparative Law, 53/4 (2005): 799.

18 Marshall Hodgson, The Venture of Islam: Conscience and History in A World Civilization (Chicago: The University of Chicago Press, 1974), 124

19 Hidayatul Ihsan dan Shahul Hameed Mohamed Ibrahim, 'Waqf Accounting and Possible Use of SORP 2005 to Develop Waqf Accounting Standards,' dalam Essential Readings in Contemporary Waqf Issues, ed. Kahf, Monzer dan Siti Mashitoh Mahamood (Kuala Lumpur: CERT Publications, 2011), 252.

20 Siti Mashitoh Mahamood, Waqf in Malaysia: Legal and Administrative Perspective (Kuala Lumpur: University Malaya Press, 2006), 91; Sohaimi Mohd Salleh \& Syarqawi Muhammad, 'Waqaf Development in Malaysia: Issues and Challenges,' Jurnal Pengurusan JAWHAR, 2/1 (2008): 21; Anan C. Mohd, 'Senario Pembangunan Waqf di Malaysia: Waqaf Melestarikan Pembangunan Ummah,' (Makalah, Seminar Antarabangsa 2014, 7-10 Disember 2014). 
antara faktor utama yang menghimpit agenda pembangunan harta wakaf di negara ini. Zarqa menyifatkan bahawa kebanyakan pentadbir harta wakaf tidak mempunyai sumber pendapatan yang mencukupi untuk membiayai aktiviti pembangunan lantas mengakibatkan wakaf tidak dapat berfungsi secara total dalam merealisasikan objektif memelihara kebajikan ummah. ${ }^{21}$ Di Malaysia misalnya, insiden "Kaya Aset, Kurang Dana" berlaku disebabkan sebahagian besar aset wakaf di negara ini adalah dalam bentuk harta tetap (harta tak alih) seperti tanah yang kurang berpotensi untuk dimajukan dan kurang mempunyai kecairan untuk dibangunkan. ${ }^{22}$ Manakala hanya sebahagian kecil daripada aset wakaf terdiri daripada harta alih seperti wang tunai. Data yang diperoleh daripada negeri Selangor pada tahun 2014 misalnya menunjukkan 97\% daripada aset wakaf di negeri berkenaan adalah dalam bentuk aset hartanah sementara hanya 3\% dalam bentuk wang tunai dengan anggaran aset hartanah bernilai RM134 juta manakala aset tunai hanya berjumlah RM5 juta. ${ }^{23}$ Maklumat tersebut jelas menunjukkan bahawa kebanyakan aset yang diwakafkan di negara ini terdiri daripada aset hartanah kekal dan masyarakat Malaysia secara amnya masih kurang membudayakan amalan berwakaf dalam bentuk harta alih seperti wang tunai, saham dan sebagainya.

Secara amnya, nilai aset hartanah wakaf di seluruh Malaysia dianggarkan bernilai RM1 bilion dengan jumlah keluasan tanah wakaf berjumlah 11,000 hektar. ${ }^{24}$ Daripada jumlah tersebut, dianggarkan hanya $0.027 \%$ daripada tanah wakaf di seluruh negara telah dibangunkan manakala selebihnya terbiar sepi disebabkan masalah kekurangan dana. ${ }^{25}$ Senario ini jelas menggambarkan

21 Muhammad Anas Zarqa, 'Financing and Investment in Awqaf Projects: A NonTechnical Introduction,' Islamic Economic Studies, 1/2 (June 1994): 59.

22 Aminah Mohsin \& Mohammad Tahir Mohammad Sabit, 'Weaknesses of Current Capital Raising, Financing, and Investment Methods,' Humanity, International Proceedings of Economics Development Research (IPEDR) (Singapore: IACSIT Press, 2011), 401-405.

23 Setakat bulan Oktober 2014. Lihat Abu Bakar Yang, 'Pembangunan Wakaf (Perbadanan Wakaf Negeri Selangor),' (Makalah, Seminar Waqaf Antarabangsa 2014, Hotel Istana Kuala Lumpur, 8-10 Disember 2014).

24 Anan C. Mohd, 'Senario Pembangunan Waqf di Malaysia: Waqaf Melestarikan Pembangunan Ummah,' (Kertas kerja Seminar Antarabangsa 2014, 7-10 Disember 2014).

25 Mohamad Hafiz Yusof Bakri, 'Hanya 0.027\% tanah wakaf dimajukan, JAWHAR guna perkongsian pintar atasi kekurangan dana,' Utusan Online, http://www. utusan.com.my/berita/nasional/hanya-0-027-tanah-wakaf-dimajukan-1.34733, dicapai pada 29 Julai 2015. 
bahawa ketiadaan sumber dana pembangunan yang mencukupi telah membantutkan usaha pembangunan wakaf di negara ini.

Berdasarkan kajian lepas, terdapat ramai pengkaji yang mengemukakan pandangan bahawa pengumpulan wakaf tunai dalam jumlah yang besar berperanan penting untuk membiayai pembangunan projek-projek wakaf. Selaras dengan kepesatan industri kewangan Islam, dana unit amanah Islam merupakan satu sektor dalam pasaran modal Islam yang wajar diberikan perhatian memandangkan mekanismenya melibatkan pengumpulan dana dalam jumlah yang besar. Dana wakaf tunai yang terkumpul kemudiannya akan disalurkan bagi tujuan pelaburan yang diuruskan secara cekap oleh pengurus dana profesional dan berpengalaman. Berdasarkan data daripada Suruhanjaya Sekuriti Malaysia, sehingga kini, terdapat 190 dana unit amanah Islam dengan nilai aset bersih sebanyak RM47.8 bilion.

Jika sebelum ini usaha dan tumpuan banyak diberikan kepada perlaksanaan wakaf tunai dalam masyarakat, kajian lanjut perlu dilakukan untuk meneroka potensi dana unit amanah Islam sebagai salah satu instrumen kewangan yang boleh diwakafkan selain daripada wang tunai dan saham syarikat. Dengan kapasiti saiz dana yang begitu besar, segmen dana unit amanah Islam wajar diterokai untuk melihat potensi untuk mengaplikasikan konsep wakaf dalam agihan manfaatnya bagi meluaskan amalan berwakaf. Pengenalan wakaf unit amanah juga dilihat berupaya untuk mewujudkan variasi terhadap medium untuk berwakaf dalam masyarakat di samping dapat memperluaskan amalan wakaf selaras dengan perkembangan industri kewangan Islam. Sehubungan itu, terdapat keperluan agar kajian lanjutan dapat dilakukan bagi meneroka potensi perlaksanaan wakaf unit amanah khususnya kedudukannya daripada segi hukum Syarak serta mekanisme untuk melaksanakannya.

\section{EVOLUSI ASET WAKAF DALAM BENTUK KONTEMPORARI}

Kajian kontemporari terawal berhubung dengan kedudukan harta alih sebagai subjek wakaf oleh Suhrawardy ${ }^{26}$ yang telah membuat himpunan secara komprehensif berhubung pandangan dan perbahasan yang menyentuh tentang kedudukan harta alih sebagai subjek wakaf daripada beberapa buah kitab muktabar daripada mazhab Hanafī, Malikī, Shāfi'ī dan Hanbalī. Menurut Suhrawardy, wakaf harta alih seperti al-Quran, buku, kawah, senjata dan kenderaan dianggap sebagai satu topik kontroversi dalam kalangan fuqaha

26 Al-Ma'mun Suhrawardy, 'The Waqf of Movables,' Journal of Asiatic Society of Bengal, 7 (1911): 324-430. 
disebabkan ciri-cirinya yang terdiri daripada harta benda yang tidak kekal. Tumpuan kajian beliau adalah terhadap kedudukan wang dan saham syarikat sebagai subjek wakaf kerana kedua-duanya tidak mempunyai karakter kekal kerana akan habis setelah digunakan sebagaimana makanan, minyak wangi dan lilin. Suhrawardy turut menukilkan fatwa daripada Mufti Besar Mesir yang telah mengeluarkan fatwa seawal tahun 1908 termasuk fatwa Muhammad Bakhit al-Muti‘i, Mufti Masjid Al-Azhar berhubung keharusan mewakafkan instrumen kewangan seperti sekuriti kerajaan, saham, bon dan saham syarikat perdagangan yang diperkenalkan oleh masyarakat Eropah yang disandarkan kepada ta'amul atau amalan masyarakat setempat di beberapa wilayah Islam seperti di Turki dan India. ${ }^{27}$

Syed Ameer $\mathrm{Ali}^{28}$ telah mendokumentasikan pandangan tentang keharusan mewakafkan harta alih dalam bentuk instrumen kewangan moden seperti sekuriti kerajaan, saham syarikat, debentur dan sebarang aset dalam transaksi perniagaan. Walau bagaimanapun, menurut Wilson, ${ }^{29}$ terdapat beberapa keputusan Mahkamah Tinggi di bawah naungan British di India sekitar tahun 1881 yang memberikan pandangan yang berbeza berhubung kesahan wakaf wang, saham syarikat dan instrumen-instrumen pelaburan moden yang didapati bercanggah dengan ketetapan hukum Syarak yang mengharuskan wakaf dalam bentuk sedemikian.

Kajian mengenai amalan wakaf tunai secara komprehensif seterusnya didokumentasikan oleh Jon Mandaville. Beliau merekodkan perbahasan kontroversi berhubung amalan wakaf tunai di Empayar Turki Uthmaniyyah berikutan terdapat pandangan konservatif daripada golongan minoriti yang menentang amalan wakaf tunai kerana tidak menepati syarat kekal. ${ }^{30}$ Menurut Cizacka $^{31}$ dan Magda, ${ }^{32}$ tidak dapat dipastikan berhubung tarikh sebenar

27 Al-Ma'mun Suhrawardy, 'The Waqf of Movables,' 372-373.

28 Syed Ameer Ali, Mahommedan Law: Compiled from Authorities in the Original Arabic (Calcutta: Thacker, Spink and Co., 1965), 246.

29 Roland Knyvet Wilson, Anglo-Muhammadan Law: A Digest Preceded by A Historical and Descriptive Introduction of the Special Rules Now Applicable to Muhammadans As Such by the Civil Courts of British India, with Full References to Modern and Ancient Authorities (London: W. Thacker, 1912), 347.

30 Jon, E., Mandaville, 'Usurious Piety: The Cash Awqaf Controversy in the Ottoman Empire,' International Journal of Middle Eastern Studies, 10/3 (1979): 289-308.

31 Murat Cizakca, A History of Philanthropic Foundations: The Islamic World from the Seventh Century to the Present (Istanbul: Bogazici University Press, 2000), $82-85$.

32 Magda Ismail Abdel Mohsin, Cash Waqf: A New Fincancial Product (Petaling Jaya: Prentice Hall, 2009), 39. 
titik permulaan amalan wakaf tunai dalam dunia Islam memandangkan tiada rekod mengenainya dalam sejarah peradaban Islam sepanjang tempoh antara kurun ke-8 hingga ke-15. Begitu juga tiada bukti yang jelas sama ada amalan wakaf tunai di Turki dipengaruhi oleh praktis masyarakat Eropah atau merupakan suatu amalan yang diwarisi semenjak zaman Rasulullah SAW. Walau bagaimanapun, keharusan amalan wakaf tunai disandarkan kepada pandangan Imam Zufar yang merupakan salah seorang pengikut Imam Abū Hanīfah. Beliau telah mengeluarkan pendapat yang membenarkan wakaf harta tidak alih termasuk wakaf dinar dan dirham melalui pelaburan dalam kontrak mudarabah dan hasilnya digunakan bagi tujuan kebajikan. ${ }^{33}$

Kajian oleh Cizakca menunjukkan amalan wakaf tunai telah dilaksanakan secara meluas di Turki malah turut disahkan oleh keputusan mahkamah di bawah Empayar Turki Uthmaniyyah seawal kurun ke-15. Kajian oleh beliau juga mendapati pada peringkat awal, amalan wakaf tunai hanya dilaksanakan di beberapa wilayah di bawah naungan Kerajaan Turki Uthmaniyyah selain daripada negara Arab kerana dianggap sebagai suatu amalan kebiasaan (ta'amul) oleh masyarakat setempat di Turki tetapi bukan di wilayah yang didiami oleh orang Arab. Hasil dapatan kajian oleh Cizakca juga menunjukkan lebih daripada 20\% wakaf tunai yang wujud semasa era Empayar Turki Uthmaniyyah terus kekal selama lebih 100 tahun. ${ }^{34}$ Hal ini membuktikan wakaf dalam bentuk harta alih berupaya dipertahan daripada sudut kekekalannya meskipun tidak mempunyai jasad sekiranya diuruskan secara cekap.

Walau bagaimanapun, Cizakca berpandangan amalan wakaf tunai atau istiglal yang mendominasi bentuk perwakafan di Turki hakikatnya tidak menyumbang kepada kemajuan ekonomi di empayar tersebut meskipun skim tersebut berperanan sebagai institusi pengumpulan modal dengan memberi pinjaman modal kepada orang awam. ${ }^{35}$ Ini disebabkan pihak-pihak yang

33 Magda Ismail Abdel Mohsin, Cash Waqf: A New Fincancial Product, 22-23.

34 Murat Cizakca, A History of Philanthropic Foundations, 52.

35 Kesan ketara daripada perlaksanaan wakaf tunai berasaskan konsep istiglal yang berkembang semasa pemerintahan kerajaan Turki Uthmaniyyah ialah lahirnya skim pasaran modal dengan dua peringkat pasaran (two-tier). Senario yang berlaku ialah pihak yang membuat pinjaman daripada wakaf tunai dengan kadar yang rendah kemudiannya akan meminjamkan wang yang diperoleh kepada sarraf di Istanbul yang menawarkan pulangan atau keuntungan yang lebih tinggi. Menerusi kaedah ini, peminjam memperoleh keuntungan menerusi perbezaan kadar yang ditawarkan oleh wakaf tunai dan sarraf. Proses tersebut adalah menyerupai sistem perbankan deposit secara konvensional yang dilaksanakan oleh Barat dan sarraf secara tidak langsung boleh diandaikan berperanan sebagai bank deposit di Empayar Turki. Lihat Murat Cizakca, A History of Philanthropic Foundations, 53-54. 
mendapat pembiayaan daripada institusi wakaf bukanlah terdiri daripada kalangan peniaga sebaliknya sebahagian besar daripada mereka adalah pemegang amanah wakaf itu sendiri. ${ }^{36}$ Pandangan ini berbeza dengan Tunku Alina dan Magda yang merumuskan bahawa amalan wakaf tunai telah memberi impak yang besar terhadap pembangunan sosioekonomi dalam Empayar Turki Uthmaniyyah dalam menyediakan khidmat pinjaman kepada ramai golongan isi rumah termasuk peniaga dalam menjana pendapatan mereka ${ }^{37}$ serta pembinaan infrastruktur asas. ${ }^{38}$

Perlaksanaan wakaf tunai sebagai salah satu bentuk harta alih telah menghasilkan variasi instrumen wakaf dalam bentuk kontemporari seperti saham wakaf dan wakaf saham. Meskipun fatwa pengharusan subjek wakaf dalam bentuk instrumen kewangan moden seperti saham dan bon telah dikesan seawal kurun ke-20, ${ }^{39}$ namun perlaksanaannya di Turki hanya dikenal pasti pada tahun 1967 menerusi perwakafan saham syarikat oleh Vehbi Koc. ${ }^{40}$

Evolusi subjek wakaf dalam bentuk harta alih seperti wakaf tunai juga melahirkan konsep saham wakaf yang telah dilaksanakan secara meluas di kebanyakan negeri di Malaysia sebagaimana yang telah didokumentasikan oleh Siti Mashitoh Mahamood ${ }^{41}$ dan Naziree Md. Yusof.42 Siti Mashitoh Mahamood berpendapat bahawa perlaksanaan saham wakaf dan wakaf tunai sememangnya berperanan penting dalam menyediakan sumber dana bagi memajukan aset-aset wakaf, di samping memupuk budaya berwakaf dalam

36 Murat Cizakca, A History of Philanthropic Foundations, 49.

37 Tunku Alina Raja Muhd Alias, 'Venture Capital Strategies in Waqf Fund Investment and Spending,' ISRA International Journal of Islamic Finance, 4/1 (2012): 100.

38 Magda Ismail Abdel Mohsin, Cash Waqf: A New Financial Product, 26-29.

39 Syed Ameer Ali, Mahommedan Law: Compiled from Authorities in the Original Arabic, 246; Roland Knyvet Wilson, Anglo-Muhammadan Law: A Digest Preceded by A Historical and Descriptive Introduction of the Special Rules Now Applicable to Muhammadans As Such by the Civil Courts of British India, with Full References To Modern and Ancient Authorities (London: W. Thacker, 1912), 347.

40 Murat Cizakca, Islamic Capitalism and Finance, 105.

41 Siti Mashitoh Mahamood et al., 'Konsep dan Aplikasi Produk Wakaf Kontemporari di Malaysia: Saham Wakaf dan Wakaf Saham,' (Makalah, Seminar Ekonomi Islam Peringkat Kebangsaan 2009, Akademi Pengajian Islam, Universiti Malaya, 10-11 Februari 2009).

42 Naziree Md. Yusof, 'Saham Wakaf Selangor: Hala Tuju dan Potensi dalam Pembangunan Masyarakat,' 29-46. 
masyarakat. ${ }^{43}$ Sementara Naziree turut menyarankan agar sektor korporat di Malaysia mengetepikan aspek keuntungan material semata-mata sebaliknya turut memberi tumpuan terhadap aspek kebajikan sosial menerusi wakaf. ${ }^{44}$ Sinergi antara sektor korporat dengan Majlis Agama Islam Negeri-Negeri juga berupaya untuk mentransformasikan usaha pembangunan wakaf ke suatu tahap yang lebih dinamik tanpa mengharapkan kebergantungan kepada dana kerajaan.

Abdul Shakor Borham ${ }^{45}$ telah membuat kajian tentang penglibatan sektor korporat dalam agenda wakaf buat julung kalinya menerusi wakaf saham oleh Johor Corporation (JCorp) pada tahun 2006. Beliau juga telah membuat tinjauan berhubung dengan proses istibdal saham syarikat tersenarai, Johor Land yang digantikan dengan unit-unit saham Al-Aqar Healthcare REIT (dahulunya dikenali sebagai Al-Aqar KPJ REIT) dengan prestasi yang stabil sepanjang penubuhannya. Perkembangan ini jelas membuktikan bahawa instrumen yang berasaskan dana amanah pelaburan hartanah seperti I-REIT mempunyai prestasi yang meyakinkan dalam membiayai kos penambahbaikan infrastruktur milik KPJ ke arah menaik taraf perkhidmatan kesihatan di Malaysia. Malah sebahagian unit-unit saham I-REIT yang diwakafkan telah disalurkan bagi tujuan wakaf khayrī (kebajikan). ${ }^{46}$

Seterusnya, kajian oleh Abdul Jalil Borham ${ }^{47}$ dan Tunku Alina ${ }^{48}$ mendapati bahawa terdapat kebarangkalian usaha pemodenan negeri Johor yang dilakukan oleh Sultan Abu Bakar pada penghujung abad ke-19 telah diinspirasikan oleh gerakan reformasi di Turki, berikutan baginda telah menggubal Majallah Ahkam Johor pada tahun 1893 berdasarkan kepada Turkish Mejelle. Sehubungan itu, berkemungkinan urusan pentadbiran, perundangan dan hal ehwal agama Islam termasuk wakaf di Turki turut mempengaruhi pemerintah di

43 Siti Mashitoh Mahamood et al., 'Konsep dan Aplikasi Produk Wakaf Kontemporari di Malaysia: Saham Wakaf dan Wakaf Saham.'

44 Naziree Md. Yusof, 'Saham Wakaf Selangor: Hala Tuju dan Potensi dalam Pembangunan Masyarakat,' Kanun, 22/4 (Disember, 2010): 36.

45 Abdul Shakor Borham, 'Pelaksanaan Pembangunan Wakaf Korporat Johor Corporation Berhad (JCorp): Satu Tinjauan,' 8.

46 Nooh Gadot, 'Transformasi Pengurusan Wakaf Johor: Pemangkin Sosio Ekonomi Ummah,' (Makalah, Seminar Waqaf Antarabangsa, Hotel Istana, 8-10 Disember 2014), 10-11.

47 Abdul Jalil Borham, Majalah Ahkam Johor: Latar Belakang, Pelaksanaan dan Komentar (Kuala Lumpur: Universiti Teknologi Malaysia, 2002), 71.

48 Tunku Alina, 'Unleashing the Potential of the Waqf As an Economic Institution in Malaysia: Policy, Legal and Economic Reforms,' (Tesis kedoktoran, International Centre for Education in Islamic Finance, Kuala Lumpur, 2011), 146-147. 
negeri Johor sehingga memberi laluan kepada anak syarikat negeri berkenaan iaitu JCorp untuk merealisasikan wakaf saham. Senario ini barangkali turut memberi impak positif terhadap aspek pengurusan wakaf di negeri Johor yang juga dilihat sebagai antara MAIN yang proaktif dalam mempromosi dan memajukan aset wakaf di Malaysia.

Dalam perkembangan lain, Cizakca merupakan antara penyelidik yang menyokong pandangan Monica Gaudiosi yang berpendapat penubuhan dana unit amanah (unit trust atau mutual fund) telah dipinjam oleh Barat daripada konsep wakaf ${ }^{49}$ iaitu wang yang terkumpul daripada para pelabur disatukan untuk membentuk suatu kumpulan dana amanah yang kemudiannya diurus dan dilaburkan oleh pengurus dana. Menurut Cizakca, struktur unit amanah yang memisahkan peranan pelabur dan pengurus dana hampir menyamai dengan konsep pengurusan wakaf secara tradisional yang memisahkan peranan pewakaf dan mutawalli. ${ }^{50}$ Lantaran itu, beliau berpendapat bahawa unit amanah merupakan satu instrumen kewangan yang berpotensi untuk diaplikasi dan dipopularkan sebagai suatu bentuk wakaf yang baharu memandangkan saiz dananya yang semakin besar dan berkembang pesat di negara-negara Islam. ${ }^{51}$

Keharusan mewakafkan instrumen kewangan seperti saham dan sukuk turut dibincangkan dalam beberapa kertas kajian yang dibentangkan dalam persidangan Majma' al-Fiqh al-Islami pada tahun 2009 antaranya oleh Siti Mashitoh Mahamood dan Shamsiah Mohamad, ${ }^{52}$ Khalifah Babkir al-Hasan ${ }^{53}$ dan Hamzah Hussein. ${ }^{54}$

Majma' al-Fiqh al-Islami dalam persidangan pada 26 April 2009 ketika membincangkan mengenai hukum wakaf saham, sukuk, harta intelek dan unit amanah pelaburan telah membuat keputusan bahawa kesemua instrumen

\footnotetext{
49 Murat Cizakca, A History of Philanthropic Foundations, 90.

50 Murat Cizakca, A History of Philanthropic Foundations, 90

51 Murat Cizakca, A History of Philanthropic Foundations, 117-121. SDA

52 Siti Mashitoh Mahamood \& Shamsiah Mohamad, 'Waqf al-Ashām wa al-Sukūk wa Huqūq al-Ma'nawiyyah wa al-Manāfi', (Makalah, Munazzamah al-Mu'tamar al-Islamī, Majma‘ al-Fiqh al-Islāmī al-Duwalī, al-Dawrah al-Tāsi'ah, United Arab Emirates, 2009).

53 Khalifah Babkir Al-Hasan, 'Hukm Waqf al-Ashām, wa al-Sukūk wa al-Manāfi'” (Makalah, Munazzamah al-Mu'tamar al-Islāmī', Majma' al-Fiqh al-Islāmī alDuwalī, al-Dawrah al-Tāsi'ah, United Arab Emirates, 2009), 5.

54 Hamzah Hussein, 'Hukm Waqf al-Ashām, wa al-Sukūk wa Huqūq alMa'nawiyyah,' (Makalah, Munazzamah al-Mu'tamar al-Islamī, Majma' al-Fiqh al-Islāmī al-Duwalī, al-Dawrah al-Tāsi'ah, United Arab Emirates, 2009), 8.
} 
kewangan tersebut adalah suatu harta yang diiktiraf oleh Syarak. Oleh itu, harus mewakafkan aset-aset dalan kategori tersebut sebagaimana hartaharta yang lain. Bahkan lebih jauh lagi, Resolusi Majma' al-Fiqh al-Islami juga membenarkan wakaf yang berbentuk sementara (muaqqat). Dalam hal ini, Majma' Fiqh telah mengambil pendapat yang dikemukakan oleh mazhab Malikī dan pandangan Abū Yūsuf daripada mazhab Hanafī. Pandangan ini merupakan suatu lonjakan yang berupaya memberikan impak yang besar kepada perkembangan wakaf sebagai sebuah institusi perekonomian masa kini.

Badan Penasihat Syariah AAOIFI juga mengambil pendirian yang sama. Piawaian Syariah no. 33, berkenaan dengan wakaf menyebut dengan jelas tentang keharusan perwakafan ke atas instrumen-instrumen kewangan tersebut. Sebagaimana pandangan Majma' Fiqh, AAOIFI juga mengiktiraf wakaf yang bersifat sementara. ${ }^{55}$

\section{KEDUDUKAN UNIT AMANAH SEBAGAI HARTA}

Unit amanah merupakan satu dokumen yang mempunyai nilai kewangan kerana ia mempunyai pemilikan dalam aset-aset yang diwakili oleh unit tersebut. Sebagai contoh, jika unit amanah tersebut melakukan pelaburan di dalam saham-saham, maka pemilikan unit amanah merujuk kepada pemiilikan ke atas saham-saham tersebut. Jika unit amanah tersebut adalah unit amanah yang melabur dalam sukuk, maka pemilikan unit amanah tersebut merujuk kepada hak mendapat pulangan daripada kupon sukuk tersebut. Unit amanah boleh dibeli dan dijual oleh pelabur secara bebas sebagaimana saham. Tetapi persoalannya adakah unit amanah tersebut sah dijadikan sebagai subjek wakaf, memandangkan ia bukan sahaja tidak mempunyai ciri-ciri kekal, malah ia juga boleh dipindah milik dan ditarik balik, terutamanya dalam situasi dialami oleh pelabur yang hanya memegang unit amanah untuk jangka masa pendek. Secara dasarnya, wakaf saham, sukuk, harta intelek dan unit amanah pelaburan juga telah dikenal pasti sebagai harta yang diiktiraf syarak oleh Majma' al-Fiqh alIslami pada persidangan bertarikh 26 April 2009. Maka, tiada halangan untuk semua instrumen kewangan ini diwakafkan kerana ia memenuhi syarat harta. Tambahan pula, Resolusi Majma' al-Fiqh al-Islami juga membenarkan wakaf yang berbentuk sementara (muaqqat) setelah mengambil kira pandangan yang dikemukakan oleh mazhab Malikī dan pandangan Abū Yūsuf daripada mazhab Hanafĩ. Selain itu, Badan Penasihat Syariah AAOIFI juga mengambil sikap yang sama. Piawaan Syariah No. 33, berkenaan dengan wakaf menyebut secara jelas tentang keharusan amalan wakaf ke atas instrumen-instrumen kewangan

55 Piawaian Syariah AAOIFI, Piawaian Syariah No. 33, Artikel no. 3/1/4 dan 3/4/3. 
tersebut. Seperti Majma' al-Fiqh al-Islami, AAOIFI juga menerimapakai wakaf yang bersifat sementara.

Majma' Fiqh menerusi resolusinya pada tahun 1992 berkaitan dengan saham dalam pasaran kewangan merumuskan bahawa harus bertransaksi dengan saham-saham yang diasaskan oleh perniagaan yang halal dan tidak terlibat dengan unsur riba ${ }^{56}$ dan selagi mana sebahagian aset yang diwakili oleh saham terdiri daripada harta ketara (tangible assets) atau manfaat berbanding dengan aset cair dalam bentuk wang dan hutang. ${ }^{57} \mathrm{Hal}$ ini bagi mengelakkan transaksi tersebut terlibat dengan elemen jual beli wang dengan wang yang tertakluk kepada penjualan pada harga par sebagaimana akad al-ṣarf. Dalam hal ini, kedudukan unit saham amanah dapat diqiyāskan dengan kedudukan saham sebagai suatu bukti pemilikan terhadap aset yang termasuk dalam kategori harta tak ketara (intangible asset) dan mempunyai nilai kewangan menurut hukum Syarak.

Sementara itu, daripada perspektif perundangan, kedudukan harta sama ada dalam bentuk harta alih atau tidak alih atau harta ketara atau tidak ketara dalam konteks industri kewangan telah diiktiraf menerusi Seksyen 2, Akta Perkhidmatan-Perkhidmatan Kewangan Islam 2013 yang mentakrifkan harta termasuk apa-apa sekuriti, termasuk saham dan dana. Umumnya instrumen kewangan adalah mewakili persetujuan mengenai sesuatu kontrak. Ini termasuklah hak dan obligasi yang dipersetujui obligasi untuk menerima atau membayar wang tunai atau aset kewangan yang lain. Manakala, IAS (International Accounting Standards) 32, Financial Instruments: Presentation, yang harus dibaca bersama dengan IFRS 9, Financial Instruments mendefinisikan instrumen kewangan sebagai:

"(a) cash; an equity instrument of another entity;

(c) a contractual right that:

1) allows the entity to receive cash or any other financial asset from another entity, or

2) allows the entity to exchange financial assets or liabilities with another entity under unfavourable conditions..." 58

56 Resolusi No. 63 (1/7). Lihat Resolutions and Recommendations of The Council of The Islamic Fiqh Academy 1985-2000 (Jeddah: Islamic Islamic Development Bank, 2000), 127.

57 Resolusi No. 30 (5/4), Resolutions and Recommendations of the Council of the Islamic Fiqh Academy 1985-2000, 63.

58 International Financial Reporting Standards (IFRS), IFRS Pocket Guide (t.t.p.: IFRS, 2013), 13. 
Berdasarkan definisi ini, jelas sekali bahawa unit amanah Islam adalah termasuk dalam kategori instrumen kewangan kerana mewakili pemilikan berkaitan kewangan yang membolehkan pemilik unit-unit berkenaan mendapatkan tunai menerusi pembayaran dividen dan pada masa yang sama turut menikmati kenaikan modal (capital appreciation) sebagaimana yang dijanjikan di dalam kontrak.

\section{KEDUDUKAN UNIT AMANAH SEBAGAISUBJEK WAKAF MENURUT PERSPEKTIF SYARAK DAN PERUNDANGAN WAKAF DI MALAYSIA}

Unit amanah merupakan satu bentuk harta alih yang boleh dibeli dan dijual oleh pelabur secara bebas sebagaimana saham. Penawaran unit-unit saham amanah kepada pelabur merupakan suatu kaedah yang membolehkan syarikat pengurus pelaburan mengumpulkan modal untuk membeli aset atau sekuriti di pasaran dan mengagihkan keuntungan hasil daripada pegangan aset-aset tersebut kepada para pemodal atau pelabur. Hal ini menimbulkan persoalan sama ada unit amanah sah dijadikan sebagai subjek wakaf memandangkan ia tidak mempunyai ciri-ciri kekal serta boleh bertukar tangan, dipindah milik bahkan terdapat kemungkinan juga dana tersebut dimansuhkan kerana tidak mempamerkan prestasi yang baik.

Jumhur fuqaha menggariskan bahawa antara syarat sah mawqūf ialah terdiri daripada harta yang bernilai dan dimiliki. ${ }^{59}$ Unit amanah merupakan satu dokumen yang mempunyai nilai kewangan kerana mewakili pemilikan dalam aset-aset yang direpresentasikan oleh unit tersebut. Sebagai contohnya, jika unit amanah tersebut adalah unit amanah yang dilaburkan dalam sahamsaham, maka pemilikan unit amanah tersebut pada hakikatnya menjadi bukti terhadap pemilikan unit amanah ke atas saham-saham di dalam sesuatu portfolio pelaburan. Manakala jika unit amanah dilaburkan dalam sukuk, maka pemilikan unit amanah tersebut membolehkan pemegang unit mendapat pulangan daripada kupon sukuk. Sehubungan itu, kedudukannya adalah sama dengan harta-harta lain yang boleh bertukar tangan menerusi transaksi jual beli, disedekahkan dan diwariskan.

Resolusi Majma' Fiqh al-Islami di Jeddah pada tahun 2009 telah memutuskan bahawa harus mewakafkan saham-saham syarikat yang halal

59 Mazhab Hanafĩ hanya mengharuskan harta bernilai dalam bentuk harta tak alih sahaja ('iqar), manakala harta tak alih seperti manfaat tidak diharuskan kerana tidak mempunyai fizikal atau ain. Lihat misalnya, al-Zuhaylī, Fiqh al-Islāmì wa Adillatuhu, vol. 4, 183; Șabrī, al-Waqf al-Islāmī bayna al-Nazariyyah wa alTațbiq, 223. 
di sisi Syarak termasuk sukuk, hak ma 'nawī (merujuk kepada harta intelek seperti hak cipta, cap dagangan dan paten), manfaat dan unit amanah kerana semuanya diiktiraf sebagai harta di sisi hukum Syarak. ${ }^{60}$ Resolusi tersebut turut menyebut tentang ciri-ciri wakaf saham yakni hendaklah bersifat kekal dan hanya manfaatnya sahaja disalurkan bagi tujuan wakaf. Oleh itu, apabila saham tersebut diwakafkan, maka ia tidak lagi boleh diniagakan melainkan terdapat syarat jelas daripada pewakaf yang menyatakan sebaliknya. Jika sekiranya syarikat tersebut menghadapi penggulungan, aliran tunai (proceed) yang didapati boleh ditukarkan kepada asset-aset yang lain seperti bangunan atau saham yang lain.

Terdapat beberapa perbincangan penting berkenaan dengan wakaf unit amanah yang diringkaskan seperti yang berikut:

1. Dalam situasi berlakunya perubahan status syarikat, bagi unit amanah dalam pelaburan saham, disebabkan konstituen unit amanah tersebut adalah saham-saham, terdapat kemungkinan saham-saham tersebut boleh bertukar status daripada patuh Syariah kepada tidak patuh Syariah. Dalam situasi ini, pegangan ke atas saham tersebut tidak lagi dibenarkan kerana ia tidak lagi menjadi harta yang mempunyai nilai di sisi Syarak. Oleh itu, sahamsaham tidak patuh Syariah itu hendaklah dijual. Hasil daripada jualan tersebut boleh digunakan untuk membeli saham-saham patuh Syariah yang mempunyai nilai (value) yang bersesuaian. Dalam praktis pengurusan unit amanah, hal ini tidaklah menjadi suatu isu yang besar kerana tatacara bagaimana saham-saham yang bertukar status ini akan dilupuskan serta apakah saham gantiannya akan dinyatakan dengan jelas dalam kriteria pelaburan (investment criteria).

2. Wakaf unit amanah boleh dibuat dalam dua bentuk, sama ada wakaf unit saham secara langsung atau dengan wakaf tunai yang kemudiannya digunakan untuk membeli unit amanah. Jika sekiranya yang diwakafkan ialah unit amanah secara langsung, maka unit amanah tersebut telah menjadi wakaf. Oleh itu, unit amanah tersebut tidak lagi boleh dijual beli. Dividen yang diterima akan digunakan untuk benefisiari wakaf sepertimana yang disyaratkan oleh pewakaf. Hal ini dinyatakan dengan jelas dalam Resolusi Majma' al-Fiqh al-Islami seperti yang berikut:

60 Resolusi No. 181 (7/19), 'al-Qararāt wa al-Tawșiyyat al-Dawrah al-Tasi'ah 'Ashar,' laman sesawang Majma' al-Fiqh al-Islāmì al-Duwalī, http://www. fiqhacademy.org.sa/, dicapai pada 15 Mei 2015. 


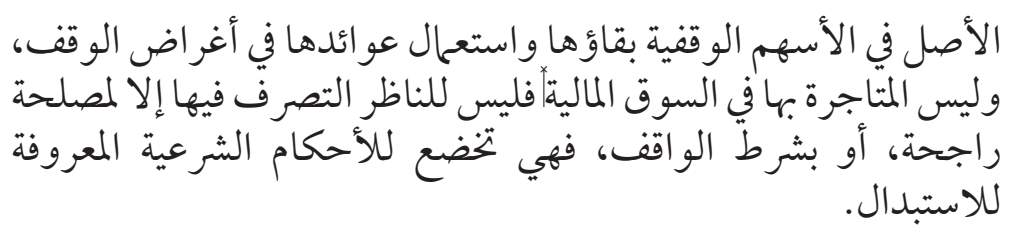

"Secara dasarnya, saham-saham yang telah diwakafkan hendaklah dikekalkan, dan hasilnya hendaklah digunakan untuk matlamat-matlamat wakaf, dan ia tidak seharusnya dijual beli di pasaran saham. Pihak nazir wakaf tidak seharusnya bertindak ke atas saham wakaf tersebut (seperti menjualnya) melainkan terdapat sesuatu maslahah yang jelas atau terdapat syarat pewakaf. Lantaran itu, saham wakaf ini adalah tertakluk kepada hukum-hukum Syarak yang berkaitan dengan istibdal”.

3. Manakala sekiranya yang diwakafkan adalah wang tunai, dan wang tunai tersebut digunakan untuk membeli unit amanah, maka pada masa tersebut, yang menjadi harta wakaf adalah nilai wang tunai dan bukannya unit saham. Ini bermakna pihak nazir boleh berjual beli unit saham tersebut dan menjadi tanggungjawabnya memastikan nilai wakaf tidak berkurangan. Pendekatan ini adalah bertepatan dengan Resolusi Majma' al-Fiqh alIslami yang menyebut:

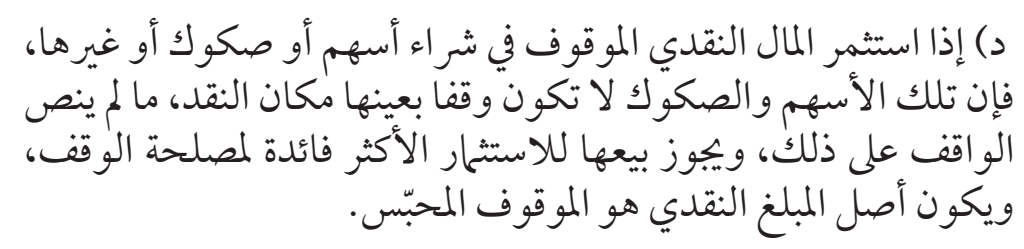

"Jika wang tunai (yang diwakafkan)digunakan untuk membeli saham, sukuk dan sebagainya, maka saham dan sukuk tersebut tidaklah menjadi harta wakaf, sebagai ganti kepada wang tunai yang telah diwakafkan, selagi mana pewakaf tidak mensyaratkan begitu. Oleh itu, saham-saham tersebut boleh dijual beli demi untuk pelaburan yang lebih mendatangkan maslahah kepada wakaf tersebut. Maka yang tetap kekal sebagai harta wakaf dan mesti dikekalkan ialah jumlah wang tunai yang asal..."

Memandangkan unit amanah termasuk dalam kategori harta bernilai maka secara tidak langsung ia menepati ciri-ciri sebagai harta yang sah untuk diwakafkan kerana termasuk dalam kategori harta yang harus dijual beli dan dimanfaatkan sebagaimana yang disepakati oleh jumhur fuqaha. Mazhab Shāfi'ī dan Hanbalī mensyaratkan harta yang diwakafkan merupakan harta 
yang dimiliki dan boleh dipindah milik menerusi jual beli. ${ }^{61}$ Manakala mazhab Malikī memperluaskan definisi tersebut merangkumi sesuatu yang boleh dimiliki, tetapi tidak boleh dijual beli seperti kulit binatang korban, anjing perburuan dan hamba sahaya yang melarikan diri yang turut boleh jadikan sebagai subjek wakaf. ${ }^{62}$

Majoriti fuqaha telah bersepakat bahawa semua wakaf hendaklah bersifat kekal dan wakaf yang mempunyai had masa yang tertentu adalah tidak sah. Berlainan dengan mazhab Malikī yang mengharuskan wakaf bertempoh atau bersifat sementara. ${ }^{63}$ Al-Dusuqi dalam mazhab Malikī telah mendefinisikan konsep kekekalan wakaf sebagai "selagi mana dan selama mana harta itu wujud". Kekekalan harta wakaf tidak wajar diukur dengan melihat jangka hayat seekor kuda atau tumbuhan atau perabot semata-mata sebaliknya, selagi mana manfaat tersebut dapat dinikmati oleh benefisiari, maka wakaf tersebut adalah menepati syarat kekal. Lantaran itu, Kahf berpendapat, wakaf bertempoh atau mempunyai jangka masa yang tertentu wajar dipertimbangkan pelaksanaannya dalam dunia moden pada hari ini bagi memenuhi objektif kebajikan sosial khususnya yang melibatkan penggunaan manfaat secara sementara seperti mewakafkan dana bagi membiayai pendidikan anak yatim sehingga tamat persekolahan; mewakafkan majalah untuk tempoh seminggu kepada perpustakaan; atau mewakafkan bayaran parkir untuk tempoh dua jam sepanjang tempoh solat Jumaat. Beliau berpendapat bahawa wakaf bertempoh sebagaimana yang diharuskan dalam mazhab Malikī wajar diperluaskan amalannya dalam masyarakat bagi memberi peluang kepada lebih ramai orang untuk berwakaf. ${ }^{64}$

Jawatankuasa Fatwa di Majlis Agama Islam Singapura (MUIS) ketika membincangkan tentang beberapa wakaf bertempoh di Singapura walau bagaimanapun telah memutuskan bahawa wakaf tersebut tidak sah kerana bersyarat had masa sedangkan tujuan wakaf adalah berkekalan (muabbad)

\footnotetext{
${ }^{61}$ Ibn Qudāmah, al-Mughnī, vol. 8, 237.

62 al-Dusūqī, Shams al-Dīn al-Shaykh Muhammad 'Arafah, Hāshiyah al-Dusūqī 'ala Sharh al- Kabīr, vol. 4, 85.

63 Namun, majoriti fuqaha bersepakat termasuk mazhab Malikī bahawa wakaf masjid adalah bersifat kekal. Lihat misalnya Șabrī, al-Waqf al-Islāmī bayna alNazariyyah wa al-Tațbīq, 177-179; Masyhūr, Athār al-Waqf fì Tanmiyyah alMujtama', 28-29.

64 Monzer Kahf, 'The Role of Waqf in Improving the Ummah Welfare', 7-8.
} 
tanpa had masa. ${ }^{65}$ Situasi ini agak berbeza dengan Malaysia yang nampaknya memberi kelonggaran dalam aspek kekekalan wakaf misalnya Akta Pentadbiran Undang-Undang Islam (Wilayah-Wilayah Persekutuan) 1993 (Akta 505) yang mengiktiraf wakaf bertempoh atau mempunyai had masa dalam tafsiran Wakaf Khas sebagai "wakaf yang berkekalan atau bagi tempoh terhad bagi maksudmaksud agama atau khairat yang diiktiraf oleh Hukum Syarak, dan harta yang diwakafkan sedemikian, yang berpendapatan (pendapatan) daripadanya diberikan kepada orang-orang atau bagi maksud-maksud yang ditetapkan dalam wakaf itu". Namun begitu fatwa berhubung dengan keharusan wakaf bertempoh ini masih belum lagi diadaptasikan oleh mana-mana negeri di Malaysia selain daripada Wilayah Persekutuan. Keharusan wakaf bertempoh turut diperakui oleh, Majma' al-Fiqh al-Islami dan Badan Penasihat Syariah AAOIFI sebagaimana yang telah dibincangkan sebelum ini.

Secara umumnya, kebanyakan harta yang diwakafkan di Malaysia terdiri daripada harta tidak alih seperti tanah dan bangunan dalam bentuk fizikal yang menjamin ciri-ciri kekekalan serta nilai manfaat yang berterusan kepada benefisiari. Dalam konteks Malaysia, Jawatankuasa Fatwa Majlis Kebangsaan Bagi Hal Ehwal Ugama Islam Malaysia kali ke-77 yang bersidang pada 10 hingga 12 April 2007 di Kuala Terengganu telah memutuskan bahawa berwakaf dalam bentuk wang tunai adalah diharuskan dalam Islam. ${ }^{66}$ Fatwa ini merupakan manifestasi berhubung pengiktirafan harta tidak alih seperti wang tunai sebagai aset yang sah untuk diwakafkan di samping boleh diqiyāskan dengan aset-aset kewangan lain seperti saham, bon dan unit amanah.

Dalam konteks perundangan di Malaysia, enakmen pentadbiran wakaf Negeri Sembilan, ${ }^{67}$ Melaka, ${ }^{68}$ Selangor, ${ }^{69}$ Johor $^{70}$ dan Pahang ${ }^{71}$ telah

65 Jawatankuasa Fatwa Majlis Agama Islam Singapura telah mengeluarkan dua fatwa bagi beberapa kes wakaf dengan tempoh masa yang telah diisytiharkan sebagai tidak sah bertarikh 13 Jun 1997 dan 6 September 2000. Lihat Shamsiah Abdul Karim, 'Contemporary Shari'ah Structuring for the Development and Management of Waqf Assets in Singapore,' 178.

66 Jabatan Kemajuan Islam Malaysia, 'Hukum Berkaitan Pembangunan Tanah Wakaf di Bawah Rancangan Malaysia Ke Sembilan (RMK-9), Wakaf Wang Tunai,' laman sesawang e-Fatwa, Jabatan Kemajuan Islam Malaysia, http://www.e-fatwa.gov. my/fatwa-kebangsaan/hukum-berkaitan-pembangunan-tanah-wakaf-di-bawahrancangan-malaysia-ke-sembilan-rmk, dicapai pada 22 Februai 2012.

67 Seksyen 11 (1) Enakmen Wakaf (Negeri Sembilan) 2005.

68 Seksyen 17 (1) Enakmen Wakaf (Melaka) 2005.

69 Seksyen 17 (1) Enakmen Wakaf (Negeri Sembilan) 1999.

70 Kaedah-Kaedah Wakaf Johor 1983 (J.P.U 51/58).

71 Kaedah-Kaedah Saham Wakaf Pahang 1998. 
mengiktiraf skim saham wakaf yang merupakan suatu variasi kepada amalan wakaf tunai. Malah wakaf saham syarikat turut diiktiraf sebagai suatu mekanisme untuk berwakaf menerusi kodifikasi undang-undang di Melaka dan Johor. Perkembangan yang menarik dapat dilihat di Negeri Sembilan apabila Seksyen 11 (2), Enakmen Wakaf Negeri Sembilan 2005 telah memperuntukkan mengenai penubuhan skim wakaf daripada kategori harta alih seperti saham wakaf, bon wakaf dan "surat cara lain bagi jaminan berharga". Dalam hal ini, saham unit amanah berkemungkinan boleh dikategorikan dalam definisi "surat cara lain bagi jaminan berharga" yakni instrumen kewangan yang diiktiraf sebagai subjek wakaf. Sehubungan itu, jelas sekali bahawa perlaksanaan wakaf unit amanah mempunyai potensi untuk direalisasikan di negara ini melalui fatwa yang bersifat dinamik ke arah memperluas amalan berwakaf dalam masyarakat.

Siti Mashitoh Mahamood dan Shamsiah Mohamad turut berpendapat bahawa unit amanah adalah sah untuk diwakafkan sebagaimana saham syarikat di mana keuntungan yang diperoleh daripada pegangan saham dan unit amanah akan disalurkan bagi tujuan benefisiari wakaf seperti yang ditentukan. ${ }^{72}$ Perkara ini turut diperakui oleh Mohd. Daud Bakar ${ }^{73}$ Monzer $\mathrm{Kahf}^{74}$ dan Engku Rabiah ${ }^{75}$ yang berpendapat bahawa harus mewakafkan unit amanah dengan mewakafkan keseluruhan atau sebahagian unit yang dipegang. Di samping itu, pelabur juga mempunyai pilihan untuk menyalurkan sejumlah tertentu daripada dividen misalnya $10 \%$ atau 50\% untuk tujuan wakaf. Engku Rabiah berpendapat bahawa hanya unit amanah Islam sahaja yang harus untuk

72 Siti Mashitoh Mahamood \& Shamsiah Mohamad, 'Waqf al-Ashām wa al-Sukūk wa Ḥuqūq al-Ma'nawiyyah wa al-Manāfi',' 2-3.

73 Petikan transkripsi: “...Saya fikir secara teknikal tidak ada bantahan untuk mewakafkan unit amanah, saham atau sukuk...," Mohd. Daud Bakar (Pengerusi Amanie Advisors dan Pengerusi Majlis Penasihat Syariah Bank Negara Malaysia dan Suruhanjaya Sekuriti Malaysia), dalam temu bual beliau dengan penulis, pada 5 Disember 2014.

74 Petikan transkripsi: "Units trust can be made waqf, if they are without a permit to trade, mawqüf units themselves remain waqf and only their revenues (not to include capital appreciation) is to be distributed to the beneficiaries...," Monzer Kahf (Profesor, Qatar Faculties of Islamic Studies), dalam temu bual beliau menerusi emel pada 25 Disember 2014).

75 Petikan transkripsi: “Boleh je nak mewakafkan unit trust...," Engku Rabiah Adawiah Engku Ali (Profesor Madya, International Islamic Banking and Finance Institution (IiBF), Universiti Islam Antarabangsa Malaysia), dalam temu bual beliau dengan penulis pada 13 Oktober 2014. 
diwakafkan bagi memastikan hasil pendapatan yang dijana adalah daripada aktiviti perniagaan yang patuh Syariah sahaja. ${ }^{76}$

Sementara itu, menurut Mohd. Daud Bakar, secara teorinya tiada halangan untuk mewakafkan unit amanah, saham dan sukuk dengan syarat pemilikan instrumen tersebut diserahkan kepada pemegang amanah dan sebarang proses jual dan beli instrumen tersebut akan dihentikan serta-merta. Sebagai contoh, sekiranya seorang pelabur membeli unit amanah daripada syarikat saham amanah ABC dan kemudian mewakafkan unit amanah yang dibeli, maka syarikat $\mathrm{ABC}$ akan menjadi pemilik kepada unit amanah tersebut dan mengambil manfaat daripada hasil dividen (bagi tujuan pengembangan aset serta kebajikan) dengan menetapkan syarat bahawa unit tersebut tidak boleh dijual lagi kepada pasaran. Dalam hal ini, pemegang amanah juga diberi kepercayaan untuk menguruskan wakaf unit amanah secara bijaksana bagi tujuan mengekalkan wakaf misalnya mencairkan unit tersebut dengan menjualnya kepada pasaran secara istibdal atas dasar mașlahah bagi mengekalkan wakaf berkenaan. ${ }^{77}$

Mohd Daud Bakar turut berpendapat harus menjual unit-unit amanah untuk suatu tempoh masa tertentu misalnya lima tahun dengan menetapkan syarat di dalam kontrak antara syarikat dana dan pelabur bahawa unit-unit tersebut akan ditebus atau dijual kembali kepada syarikat selepas tempoh misalnya lima tahun. Dalam hal ini, unit-unit berkenaan dapat diedarkan secara terkawal kepada para pelabur. Menurut beliau, mekanisme ini diharuskan atas dasar mașlahah bagi memelihara kepentingan aset wakaf dengan tujuan mendapatkan dana untuk membiayai pembangunan wakaf. ${ }^{78}$

76 Petikan transkripsi: "Kalau nak buat wakaf, Islamic REIT yang boleh diwakafkan, kalau REIT yang konvensional takut ada income yang non-halal...," Engku Rabiah Adawiah Engku Ali (Profesor Madya, International Islamic Banking and Finance Institution (IiBF), Universiti Islam Antarabangsa Malaysia), dalam temu bual beliau dengan penulis pada 13 Oktober 2014.

77 Petikan transkripsi: "If the trustee want to sell it to the market through istibdal, it is subject to the board of trustee endorsement for good reason that they want to cash out, take the money to do something else..., " Mohd. Daud Bakar (Pengerusi Amanie Advisors dan Pengerusi Majlis Penasihat Syariah Bank Negara Malaysia dan Suruhanjaya Sekuriti Malaysia), dalam temu bual beliau dengan penulis, pada 5 Disember 2014.

78 Mohd. Daud Bakar (Pengerusi Amanie Advisors dan Pengerusi Majlis Penasihat Syariah Bank Negara Malaysia dan Suruhanjaya Sekuriti Malaysia), dalam temu bual beliau dengan penulis, pada 5 Disember 2014. 


\section{KESIMPULAN}

Secara teorinya, berdasarkan pandangan pakar-pakar dalam bidang wakaf dan kewangan Islam serta fatwa oleh Majma' Fiqh al-Islami, mewakafkan instrumen kewangan seperti saham, sukuk dan unit amanah Islam adalah sah. Namun daripada sudut implementasi, wakaf dalam bentuk sedemikian rupa masih belum dipraktikkan secara meluas oleh umat Islam. Hal ini mungkin disebabkan terdapatnya beberapa isu Syariah yang perlu diperhalusi khususnya yang menyentuh aspek pemindahan hak milik unit yang diwakafkan serta isu pengurusan risiko.

Berdasarkan perbincangan sebelum ini, dapat dirumuskan bahawa sekiranya unit saham amanah menjadi subjek wakaf, maka ia tidak lagi boleh diniagakan. Unit amanah tersebut hendaklah dipegang serta dikekalkan dan hanya dividennya digunakan bagi tujuan wakaf. Pihak nazir tidak seharusnya menjual unit saham amanah tersebut, melainkan jika terdapat maslahah yang jelas ataupun syarat pewakaf yang menyatakan sedemikian. Namun sekiranya subjek wakaf adalah wang tunai, dan wang tunai tersebut kemudiannya digunakan untuk membeli unit amanah, maka unit amanah yang dibeli tidak menjadi subjek wakaf, melainkan jika pewakaf mensyaratkan sebegitu. Dalam hal ini, jumlah wang tunai yang diwakafkan hendaklah dikekalkan dan unit amanah tersebut boleh diniagakan. Jika sekiranya berlaku sebarang perubahan status kepada saham yang menjadi konstituen kepada unit amanah, maka saham yang tidak lagi patuh Syariah hendaklah diganti dengan saham lain yang patuh Syariah. Tindakan ini secara praktikalnya akan dikendalikan oleh pengurus unit amanah tersebut.

Persoalan seterusnya adalah tentang kedudukan unit amanah yang diwakafkan yang terdedah kepada risiko kerugian akibat daripada ketidaktentuan prestasi pasaran. Apakah yang harus dilakukan oleh pengurus dana apabila sesebuah dana unit amanah yang diwakafkan mengalami kerugian? Dalam hal ini, adalah menjadi tanggungjawab pihak nazir untuk memastikan kesinambungan dan kestabilan harga unit amanah tersebut agar dapat mengekalkan nilai asal unit amanah yang diwakafkan. Hal ini dinyatakan dengan jelas dalam Resolusi Majma' al-Fiqh sebagai mașlaḥah rajīhah. Namun begitu, terdapat keperluan agar kajian lanjut dilakukan untuk menganalisis pendekatan pengurusan risiko yang terbaik bagi memastikan kestabilan harga unit amanah tersebut. Penyelidikan sebegini amatlah penting demi memastikan instrumen kewangan seperti unit amanah dapat dijadikan sebagai subjek wakaf di samping mencadangkan mekanisme yang sesuai bagi merealisasikan wakaf dalam bentuk kelas aset yang baharu ini. Mekanisme yang dicadangkan diharap berupaya membuka mata para pengurus dana unit 
amanah dan syarikat-syarikat dana Islam untuk menyokong agenda wakaf di negara ini secara lebih progresif dan inovatif untuk kemaslahatan dan kesejahteraan ummah sejagat.

\section{RUJUKAN}

Abdul Jalil Borham, Majalah Ahkam Johor: Latar belakang, Pelaksanaan dan Komentar (Kuala Lumpur: Universiti Teknologi Malaysia, 2002).

Abdul Shakor Borham, 'Pelaksanaan Pembangunan Wakaf Korporat Johor Corporation Berhad (JCorp): Satu Tinjauan,' (Kertas kerja dibentangkan dalam International Conference on Humanities, Park Royal Hotel, Pulau Pinang, 2011).

Abī Dāwud Sulayman Ibn al-Ash'ath, 'Sunan Ab̄̄ Dāwud', Mawsū'ah alHadìth al-Sharîf: al-Kutub al-Sittah, ed. Sālih Ibn 'Abd al-'Aziz Ibn Muḥammad Ibn Ibrāhim al-Shaykh (Riyāḍ: Dār al-Salām, 2008).

Abī 'Abd al-Rahmān Ahmad Ibn Shu'ayb al-Nasā'i, Mawsū'ah al-Hadìth alSharīf: al-Kutub al-Sittah, ed. Sālih Ibn 'Abd al-'Aziz Ibn Muhammad Ibn Ibrāhim al-Shaykh (Riyāḍ: Dār al-Salām, 2008).

Abū al-Husayn Muslim bin al-Hajjaj al-Qushayrī, 'Ṣaḥị Muslim', Mawsū 'ah al-Hadìth al-Sharīf: al-Kutub al-Sittah, ed. Sāliḥ Ibn 'Abd al-'Aziz Ibn Muhammad Ibn Ibrāhim al-Shaykh (Riyāḍ: Dār al-Salām, 2008).

Abu Bakar Yang, 'Pembangunan Wakaf(Perbadanan Wakaf Negeri Selangor),' (Kertas Kerja dibentangkan dalam Seminar Waqaf Antarabangsa 2014, Hotel Istana Kuala Lumpur, 8-10 Disember 2014).

Abū al-Husayn Muslim bin al-Hajjāj al-Qushayrī, 'Șahịḥ Muslim', Mawsū 'ah al-Hadìth al-Sharīf: al-Kutub al-Sittah, ed. Sālih Ibn 'Abd al-'Aziz Ibn Muḥammad Ibn Ibrāhim al-Shaykh (Riyāḍ: Dār al-Salām, 2008).

Abū Zahrah, Muḥāẹarāt fì al-Waqf (t.t.p.: Matba'ah 'Alī Mukhaymar, 1959).

Abū 'Abd Allāh Muḥammad bin Ismā'il al-Bukhārī, 'Ṣahị̣̄ al-Bukhārī,' Mawsū'ah al-Hadīth al-Sharīf: al-Kutub al-Sittah, ed. Sālih Ibn 'Abd al-'Aziz Ibn Muḥammad Ibn Ibrāhim al-Shaykh (Riyāḍ: Dār al-Salām, 2008).

Accounting and Auditing of Islamic Financial Institution, Shari 'a Standards For Islamic Financial Institutions (Bahrain: AAOIFI, 2010).

Al-Ma'mun Suhrawardy, 'The Waqf of Movables,' Journal of Asiatic Society of Bengal, 7 (1911): 324-430. 
Aminah Mohsin \& Mohammad Tahir Mohammad Sabit, 'Weaknesses of Current Capital Raising, Financing, and Investment Methods,' Humanity, International Proceedings of Economics Development Research (IPEDR) (Singapore: IACSIT Press, 2011), 401-405.

Anan C. Mohd, 'Senario Pembangunan Waqf di Malaysia: Waqaf Melestarikan Pembangunan Ummah,' (Kertas kerja Seminar Antarabangsa 2014, 7-10 Disember 2014).

Hamzah Hussein, 'Hukm Waqf al-Ashām, wa al-Sukūk wa Huqūq alMa'nawiyyah,' (Makalah, Munazzamah al-Mu'tamar al-Islamī, Majma‘ al-Fiqh al-Islāmī al-Duwalī, al-Dawrah al-Tāsi‘ah, United Arab Emirates, 2009).

Hidayatul Ihsan \& Shahul Hameed Mohamed Ibrahim, 'Waqf Accounting and Possible Use of SORP 2005 to Develop Waqf Accounting Standards,' dalam Essential Readings in Contemporary Waqf Issues, ed. Kahf, Monzer \& Siti Mashitoh Mahamood (Kuala Lumpur: CERT Publications, 2011).

Ibn Qudāmah, Ab̄̄ Muḥammad 'Abd Allāh bin Aḥmad bin Muḥammad, alMughnī (Riyāẹ: Dār 'Alam al-Kutub, 1997).

International Financial Reporting Standards (IFRS), IFRS Pocket Guide (t.t.p.: IFRS, 2013).

Islamic Development Bank, Resolutions and Recommendations of the Council of the Islamic Fiqh Academy 1985-2000 (Jeddah: Pengarang, 2000).

Jabatan Kemajuan Islam Malaysia, 'Hukum Berkaitan Pembangunan Tanah Wakaf di Bawah Rancangan Malaysia Ke Sembilan (RMK-9), Wakaf Wang Tunai,' laman sesawang e-Fatwa, Jabatan Kemajuan Islam Malaysia, http://www.e-fatwa.gov.my/fatwa-kebangsaan/hukum-berkai tan-pembangunan-tanah-wakaf-di-bawah-rancangan-malaysia-kesembilan-rmk., dicapai pada 22 Februai 2012.

Jon, E., Mandaville, 'Usurious Piety: The Cash Awqaf Controversy in the Ottoman Empire,' International Journal of Middle Eastern Studies, 10/3 (1979): 289-308.

Khalifah Babkir Al-Hasan, 'Hukm Waqf al-Ashām, wa al-Sukūk wa alManāfi', (Makalah, Munazzamah al-Mu'tamar al-Islāmī,' Majma‘ alFiqh al-Islāmī al-Duwalī, al-Dawrah al-Tāsi'ah, United Arab Emirates, 2009).'

Magda Ismail Abdel Mohsin, Cash Waqf: A New Fincancial Product (Petaling Jaya: Prentice Hall, 2009). 
Magda Ismail Abdel Mohsin, 'Revitalization of Waqf Administration \& Family Waqf Law,' US-China Law Review, 7/6 (2010): 1-8.

Majmā' al-Lughah al-'Arabiyyah, al-Mu'jam al-Waṣiț, vol. 2 (Qāhirah: Maktabah al-Shuruq al-Dawliyyah, 2004).

Majmā' Fiqh al-Islāmī al-Duwalī, 'al-Qararāt wa al-Tawsiyyāt al-Dawrah alTāsi'ah 'Ashar,' laman sesawang Majmā' al-Fiqh al-Islāmī al-Duwat̄, http://www.fiqhacademy.org.sa/., dicapai pada 15 Mei 2015.

Marshall Hodgson, The Venture of Islam: Conscience and History in A World Civilization (Chicago: The University of Chicago Press, 1974).

Miriam Hoexter, Endowments, Rulers and Community: Waqf al-Haramayn in Ottoman Algiers (Leiden: Brill, 1998).

Mohamad Hafiz Yusof Bakri, 'Hanya 0.027\% tanah wakaf dimajukan , JAWHAR guna perkongsian pintar atasi kekurangan dana,' Utusan Onlinehttp://www.utusan.com.my/berita/nasional/hanya-0-027-tanahwakaf-dimajukan-1.34733, dicapai pada 29 Julai 2015.

Monzer Kahf, 'The Role of Waqf in Improving the Ummah Welfare,' (Kertas kerja dibentangkan di Waqf as a Private Legal Body, University of North Sumatra, 6-7 Januari 2003).

Monzer Kahf, 'Waqf and its Sociopolitical Aspects,' dalam Essential Readings in Contemporary Waqf Issues, ed. Kahf, Monzer \& Siti Mashitoh Mahamood (Kuala Lumpur: CERT Publications, 2011).

Muhammad Anas Zarqa, 'Financing and Investment in Awqaf Projects: A NonTechnical Introduction,' Islamic Economic Studies, 1/2 (June 1994).

Muhammad Ibn Yazid al-Qazwini, 'Sunan Ibn Majah,' Mawsū 'ah al-Hadìth alSharīf: al-Kutub al-Sittah, ed. Sāliḥ Ibn 'Abd al-'Aziz Ibn Muḥammad Ibn Ibrāhim al-Shaykh (Riyāḍ: Dār al-Salām, 2008).

Muḥammad Ibn 'Isā Ibn Thawrah, 'Jami' al-Tirmidhī', Mawsū 'ah al-Hadīth alSharîf: al-Kutub al-Sittah, ed. Sāliḥ Ibn 'Abd al-'Aziz Ibn Muḥammad Ibn Ibrāhim al-Shaykh (Riyāḍ: Dār al-Salām, 2008).

Muhammad Ibn 'Īsā, 'Jāmi' al-Tirmidhī', Mawsū'ah al-Hadīth al-Sharīf: alKutub al-Sittah, ed. Sālih Ibn 'Abd al-'Aziz Ibn Muḥammad Ibn Ibrāhim al-Shaykh (Riyāḍ: Dār al-Salām, 2008).

Murat Cizakca, A History of Philanthropic Foundations: The Islamic World from the Seventh Century to the Present (Istanbul: Bogazici University Press, 2000).

Muḥammad 'Urfah al-Dusūqī, Hāshiyah al-Dusūqì 'ala al-Sharh al-Kabīr (t.t.p.: al-Bābī al-Halābī, 1998). 
Mușțafā Aḥmad al-Zarqa', al-Ahkām al-Awqāf( 'Amman: Dār 'Ammar, 1998). Naziree Md. Yusof, 'Saham Wakaf Selangor: Hala Tuju dan Potensi dalam Pembangunan Masyarakat,' Kanun, 22/4 (2010): 29-46.

Ni'mat 'Abd al-Latif Masyhurm, Athār al-Waqf fì Tanmiyyah al-Mujtama' (Qāhirah: Markaz Șāliḥ ‘Abd Allāh Kāmil li al-Iqtișād al-Islāmī, Jāmi'ah al-Azhar, 1997).

Nooh Gadot, 'Transformasi Pengurusan Wakaf Johor: Pemangkin Sosio Ekonomi Ummah,' (Kertas kerja dibentangkan di Seminar Waqaf Antarabangsa, Hotel Istana, 8-10 Disember 2014).

Roland Knyvet Wilson, Anglo-Muhammadan Law: A Digest Preceded by A Historical and Descriptive Introduction of the Special Rules Now Applicable to Muhammadans as Such by the Civil Courts of British India, with Full References to Modern and Ancient Authorities (London: W. Thacker, 1912).

Sabri, 'Ikrimah Sa'id, al-Waqf al-Islāmī bayna al-Nazariyyah wa al-Tațbīq (Urdun: Dār al-Nafā'is, 2008).

Shams al-Dīn al-Sarakhsī, al-Mabṣūt, vol. 12 (Beirūt: Dār al-Ma'rifah, t.t.).

Shamsiah Abdul Karim, 'Contemporary Shari'ah Structuring for the Development and Management of Waqf Assets in Singapore,' (Tesis kedoktoran, Durham University, United Kingdom).

Siraj Sait \& Hilary Lim, Land Law and Islam: Property Human Rights in the Muslim World (London: Zed Books Ltd., 2006).

Siti Mashitoh Mahamood \& Shamsiah Mohamad, 'Waqfal-Ashām wa al-Sukūk wa Huqūq al-Ma'nawiyyah wa al-Manāfi', (Makalah, Munazzamah alMu'tamar al-Islamī, Majma‘ al-Fiqh al-Islāmī al-Duwalī, al-Dawrah alTāsi'ah, United Arab Emirates, 2009).

Siti Mashitoh Mahamood et al., 'Konsep dan Aplikasi Produk Wakaf Kontemporari di Malaysia: Saham Wakaf dan Wakaf Saham,' (Kertas kerja yang dibentangkan di Seminar Ekonomi Islam Peringkat Kebangsaan 2009, Balai Ilmu, Akademi Pengajian Islam, Universiti Malaya, Malaya, 10-11 Februari 2009).

Siti Mashitoh Mahamood, Waqf in Malaysia: Legal and Administrative Perspective (Kuala Lumpur: University of Malaya Press, 2006).

Sohaimi Mohd Salleh \& Syarqawi Muhammad, 'Waqaf Development in Malaysia: Issues and Challenges,' Jurnal Pengurusan JAWHAR, 2/1 (2008). 
Syahnaz Sulaiman, 'Hukum Pembangunan Tanah Wakaf Khas menurut Perspektif Syarak,' Jurnal Muamalat, 1 (2008): 45-64.

Syed Ameer Ali, Mahommedan Law: Compiled from Authorities in the Original Arabic (Calcutta: Thacker, Spink and Co., 1965).

Timur Kuran, 'The Absence of the Corporation in Islamic Law: Origins and Persistence,' American Journal of Comparative Law, 53/4 (2005): 785834.

Timur Kuran, 'The Provision of Public Goods under Islamic Law: Origins, Impact, and Limitations of the Waqf System,' Law and Society Review, 35 (2001): 841-898.

Tunku Alina Raja Muhd Alias, 'Unleashing the Potential of the Waqf as An Economic Institution in Malaysia: Policy, Legal and Economic Reforms,' (Tesis kedoktoran, International Centre for Education in Islamic Finance, Kuala Lumpur, 2011).

Tunku Alina Raja Muhd Alias, 'Venture Capital Strategies in Waqf Fund Investment and Spending,' ISRA International Journal of Islamic Finance 4/1 (2012): 99-126.

Wahbah al-Zuhaylī, al-Wașāyā wa al-Waqffí al-Fiqh al-Islamī (Damshiq: Dār al-Fikr, 1987).

Wahbah al-Zuhaylī, Fiqh al-Islāmī wa Adillatuh (Damshiq: Dār al-Fikr, 1985).

Yildrim, Riza, 'Dervishes Waqfs, and Conquest: Notes on Early Ottoman Expansion in Thrace,' dalam Held in Trust: Waqf in the Islamic World, ed. Ghazaleh, Pascale (New York: The American University in Cairo Press, 2011).

\section{Statut}

Enakmen Wakaf (Melaka) 2005.

Enakmen Wakaf (Negeri Sembilan) 1999.

Enakmen Wakaf (Negeri Sembilan) 2005.

Kaedah-Kaedah Saham Wakaf Pahang 1998.

Kaedah Wakaf Johor 1983 (J.P.U 51/58).

\section{Temu bual}

Engku Rabiah Adawiah Engku Ali (Profesor Madya, International Islamic Banking and Finance Institution (IiBF), Universiti Islam Antarabangsa Malaysia), dalam temu bual beliau dengan penulis pada 13 Oktober 2014. 
Mohd. Daud Bakar (Pengerusi Amanie Advisors dan Pengerusi Majlis Penasihat Syariah Bank Negara Malaysia dan Suruhanjaya Sekuriti Malaysia), dalam temu bual beliau dengan penulis, pada 5 Disember 2014.

Monzer Kahf (Profesor, Qatar Faculties of Islamic Studies) dalam temu bual beliau menerusi emel, pada 25 Disember 2014. 
Jurnal Syariah, Jil. 25, Bil. 2 (2017) 157-186 